\title{
11. CORRELATION AND COMPARISON OF BACKARC SITES 1
}

\author{
Shipboard Scientific Party ${ }^{2}$
}

\section{INTRODUCTION}

This chapter provides a comparative, generalized, spatial, and geochronological context for the four sites that were drilled in and on the margin of the Sumisu Rift in the Izu-Bonin Arc. In the corresponding chapter on the forearc sites, Figures 1 and 2 show how the forearc and backarc sites are spatially related; the backarc sites alone are shown in Figure 1 of this chapter. Sites 788 and 789 are located on the eastern rift flank footwall uplift in water $1100 \mathrm{~m}$ deep. Sites 790 and 791 were drilled in water about twice as deep ( 2223 and $2271 \mathrm{~m}$, respectively) into the flat floor of the rift basin. Site $790,15 \mathrm{~km}$ west of Site 788, is situated on the western side of the eastern half-graben of the rift on the margin of an intrabasinal high; Site 791 was drilled $2.4 \mathrm{~km}$ east of Site 790. Each backarc site is more fully described in its own site chapter in this volume. A lithologic and graphic summary for the backarc sites is presented in Figure 2.

The sedimentary record of the eastern margin of the rift was recovered at Site 788 , from Holes $788 \mathrm{C}$ and $788 \mathrm{D}$. Recovery of the lower part of the section was poor (Hole 788D, Subunits IIA and IIB), and so the earlier lithostratigraphic record from the margin is fragmentary and must be interpreted with caution. However, recovery of the younger sediments from Hole $788 \mathrm{C}$ was good. In contrast, the sedimentary successions of the rift basin have been reconstructed from three holes at Site 790 (Holes 790A, 790B, and 790C) and two holes at Site 791 (Holes $791 \mathrm{~A}$ and 791B), at which recovery and stratigraphic overlap were reasonably good.

There is little stratigraphic overlap between the strata encountered on the rift flank uplift and in the rift basin. The sedimentary succession of the margin is older and, except for the uppermost $\sim 30 \mathrm{~m}$, entirely predates the rifting. The $30-\mathrm{m}$ surface capping of the uplift as well as the total fill of the rift basin postdate the initiation of rifting. Massive igneous rock was cored only at Site 791 in the basin. On the rift flank uplift, we did not see basement in the seismic reflection records; therefore, the igneous rock must lie far below the greatest depth reached by the drill. Scoriaceous basalts recovered from the basal interval drilled at Site 790 are probably fragmental syn-rift volcanic rocks.

\section{PLIOCENE-QUATERNARY SEDIMENTARY SUCCESSION OF THE RIFT FLANK MARGIN}

The oldest rocks recovered from the backarc region are from the base of Hole 788D (Subunit IIB, 278.6-374 mbsf), paleomagnetically dated at 4.77 to about $4.2 \mathrm{Ma}$ (early Pliocene). These rocks are mainly volcaniclastic: interbedded pumiceous conglomerate, vitric sandstone, vitric siltstone, and vitric silty claystone. They are generally low in carbonate content, but are somewhat more calcareous from the middle part of the subunit downward. Sedimentation rates varied during the deposition of this subunit from 192 to $73 \mathrm{~m} / \mathrm{m}$.y., then to $282 \mathrm{~m} / \mathrm{m}$.y. (Fig. 3).

\footnotetext{
${ }^{1}$ Taylor, B., Fujioka, K., et al., 1990. Proc. ODP, Init. Repts., 126: College Station, TX (Ocean Drilling Program).

${ }^{2}$ Shipboard Scientific Party is as given in the list of participants preceding the contents.
}

Minor faults, presumably of normal displacement associated with rifting, cut these rocks at 288-297 mbsf.

From 249 to $278.6 \mathrm{mbsf}$ (Site 788, Subunit IIA), the rocks, paleomagnetically dated at about $4.2-3.8 \mathrm{Ma}$, are also dominated by volcaniclastic components, but they do contain significant epiclastic and pelagic components. They are interbedded nannofossil-rich claystone, vitric sandstone, vitric silty claystone, and vitric siltstone; conglomerate is notably absent. Sedimentation rates were low, measured at $39 \mathrm{~m} / \mathrm{m}$.y. in the upper portion of the subunit (Site 788, Subunit IIA; see Fig. 3).

Unit I of Site 788 overlies Unit II at 249 mbsf. Unit I has an estimated basal age of $3.66 \mathrm{Ma}$ and is composed of sandy, granule, and pebble pumiceous gravel that contains little interstitial mud, locally interbedded with vitric sand and rare vitric silt. The basal $19 \mathrm{~m}$ (Subunit IB) is transitionally lithified to conglomerate. The unit is composed of four coarsening-upward intervals, each $30-50 \mathrm{~m}$ thick. The uppermost, 30-m-thick interval is biostratigraphically separated from the others by an unconformity. Below the hiatus, the age of these pumiceous gravel beds is somewhere between 2.85 and $2.36 \mathrm{Ma}$, depending upon the actual sedimentation rate, which could be as high as $230 \mathrm{~m} /$ m.y. or as low as $145 \mathrm{~m} / \mathrm{m}$.y. (Fig. 3).

The gravel layer immediately above the hiatus was biostratigraphically dated at $0.275 \mathrm{Ma}$; it accumulated at rates in excess of $115 \mathrm{~m} / \mathrm{m} . \mathrm{y}$. The age of the top of this uppermost interval is not known, but discolored pumice clasts, and a lack of interstitial mud that is exceptional even for Unit $\mathrm{I}$, indicate that the surface deposits have resided for some time at the seafloor where they were subjected to oxidation and winnowing. It is only this 30 -m surficial interval on the rift flank uplift that correlates stratigraphically with the (upper) sediments at the basin sites.

\section{PLEISTOCENE IGNEOUS ROCK OF THE RIFT BASIN SITES}

At Site $790,116 \mathrm{~m}$ of igneous rock was drilled from 271 to 387 mbsf. Recovery was poor $(0.9 \%)$, totaling only $1 \mathrm{~m}$ of scoriaceous basalt fragments, all from core catchers. The quality of seismic reflections indicates that this interval is not massive igneous rock. At Site 791, igneous rock was cored from 834 to 1145 mbsf. Recovery from this $311-\mathrm{m}$ interval was $27.83 \mathrm{~m}$, or $8.9 \%$, and consisted of a lithologically complex suite of rocks. The downhole sequence consisted of basalt breccia, basalt, a diabase intrusion, basaltic "mousse," and mafic to felsic tuff and lapilli tuff. The basalts recovered at both sites are highly vesicular and sparsely phyric, typically with olivine and plagioclase phenocrysts, although one lava at Site 791 also contains clinopyroxene.

The basalt "mousse" at Site 791 consists of clasts of highly vesicular basalt glass in a matrix of even more vesicular glass of the same composition. Inconclusive igneous-petrological evidence has led to the speculation that the tuffs at the bottom of Hole 791B may represent pre-rift sediments. The diabase intrusions at Site 791 range from olivine to clinopyroxene rich. Some volcaniclastic sedimentary material of Pleistocene age occurs in the igneous rocks of Sites 790 and 791 . At Site 790, sedimentary particles admixed with basaltic scoria contain nannofossils that indicate an age of $0.83-1.6 \mathrm{Ma}$ (Zone CN14a), but this material 


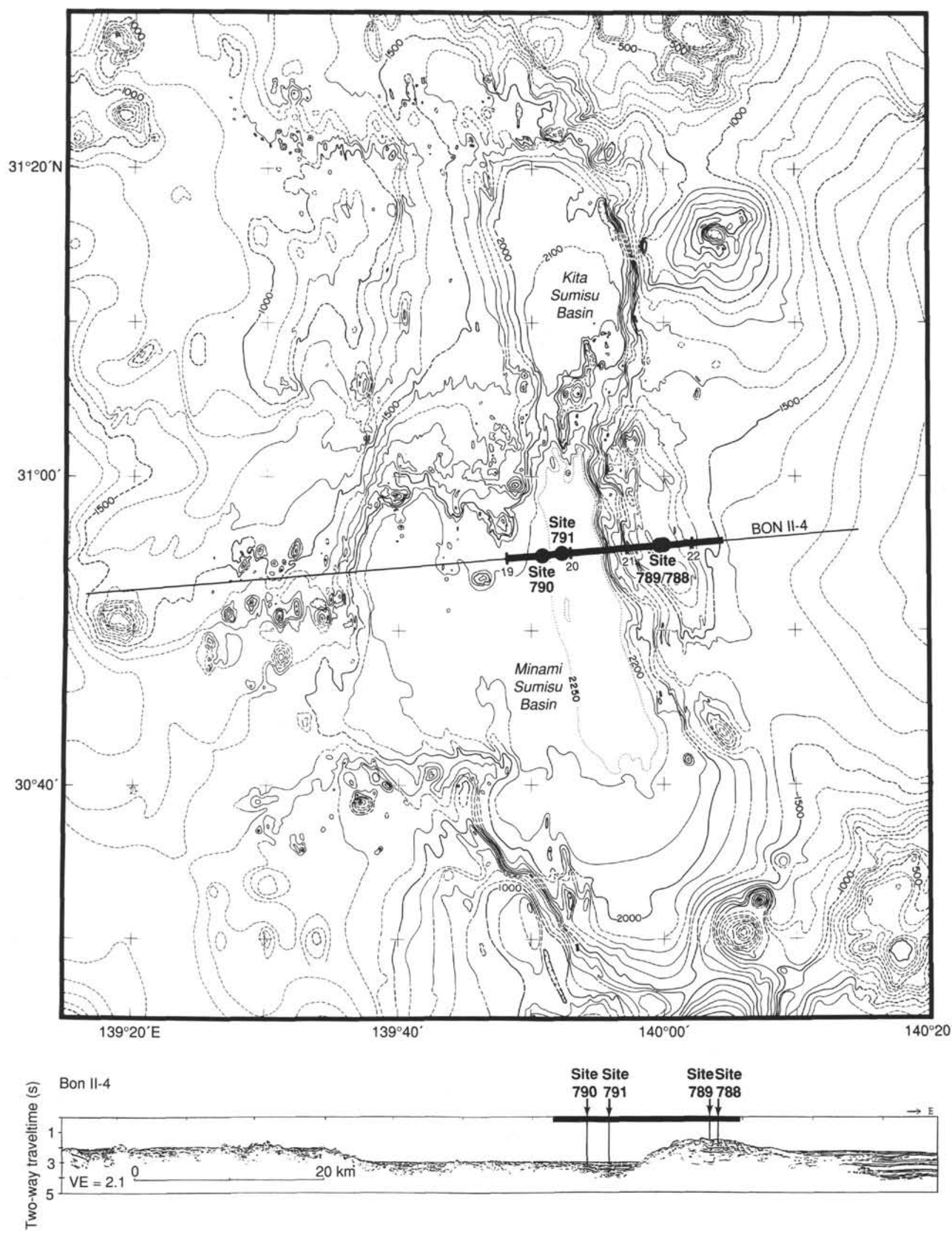

Figure 1. Bathymetry (100-m contour interval) of Sumisu Rift (modified from Taylor et al., 1988), showing the location of multichannel seismic (MCS) Line BON II-4 and the backarc sites. A line drawing of the seismic reflection profile is shown at the bottom of figure. The solid bar above the profile indicates the segment of Line BON II-4 that is depicted in Figure 2. 


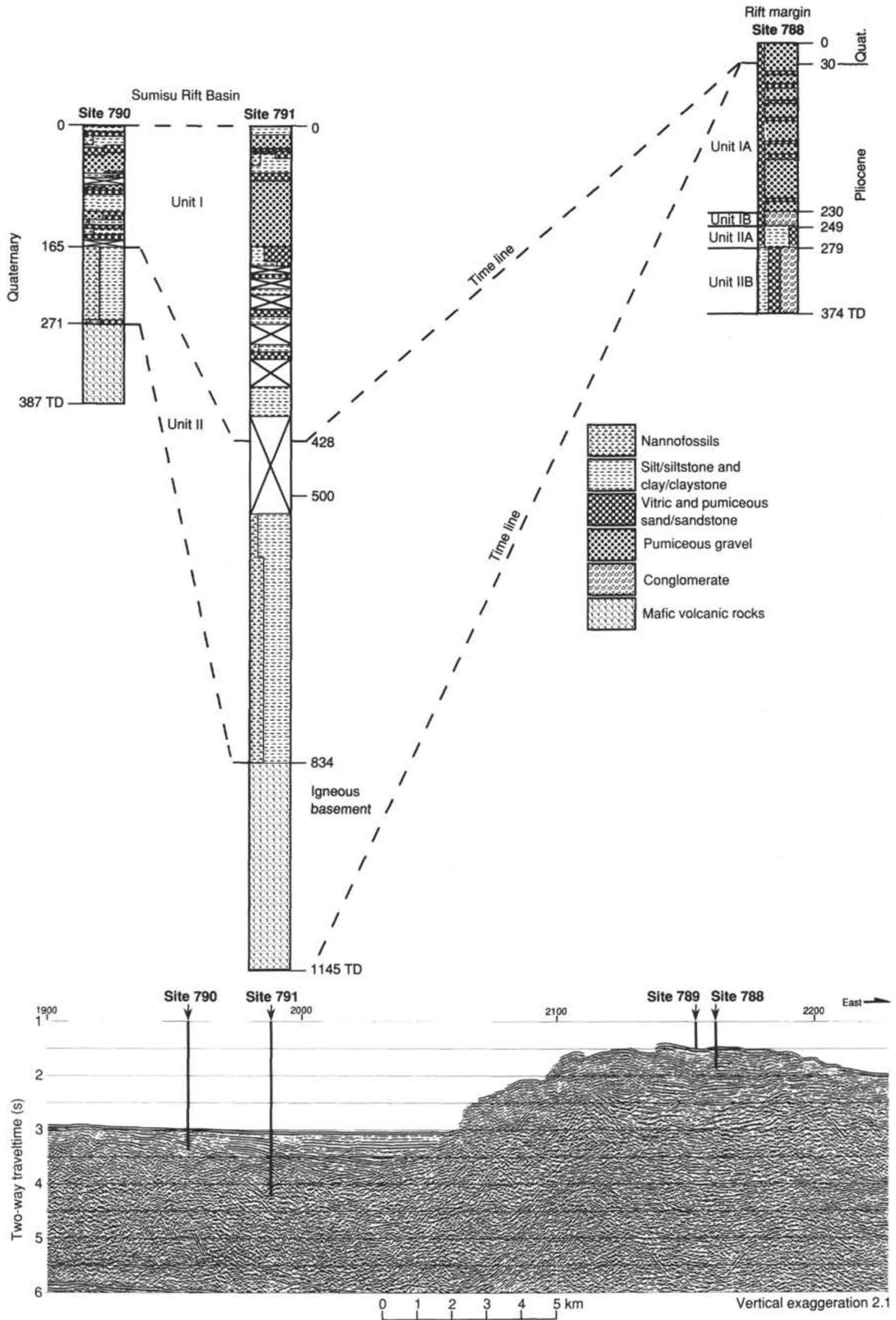

Figure 2. Stratigraphic correlation diagram for the backarc sites. The seismic profile (after Taylor et al., this volume) is the segment of MCS Line BON II-4 across the eastern footwall uplift and eastern half-graben of the Sumisu Rift. 


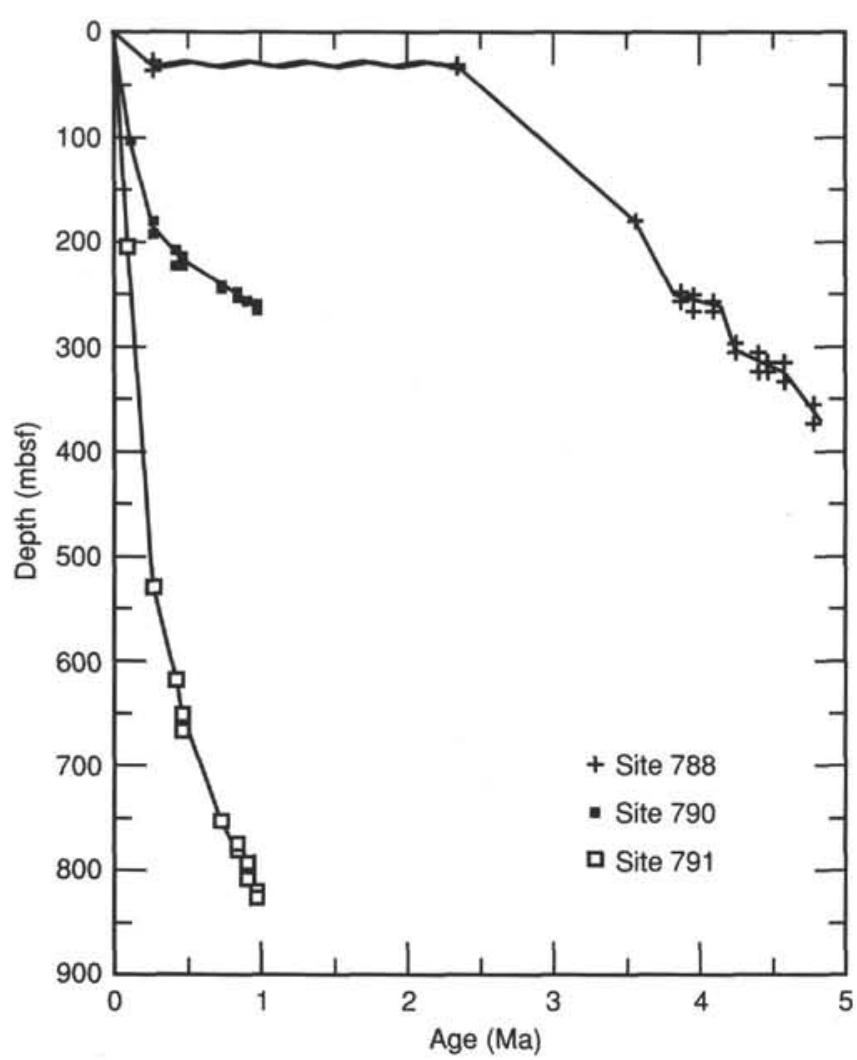

Figure 3. Age-depth plots for the backarc sites. The wavy line on the Site 788 curve is an unconformity.

may be downhole contamination. At Site 791, a 22-cm-thick interval of crystal-vitric silt and sandy mud occurs at 974 mbsf.

\section{QUATERNARY SEDIMENTARY RIFT BASIN FILL}

The sedimentary section at Site 791 is about three times thicker than the section at Site 790. The biostratigraphic and paleomagnetic data used to construct the age-depth curves (Fig. 3) indicate that the successions at the two sites are essentially time equivalent. The greater overburden pressures of the thicker column at Site 791 have compacted and lithified its basal sediments, whereas the sedimentary accumulation at Site 790 is entirely unlithified. Sedimentation rates at the base of Unit II were 90 and $344 \mathrm{~m} / \mathrm{m} . \mathrm{y}$. at Sites 790 and 791 , respectively; they increased to $\sim 1000$ and $2200 \mathrm{~m} / \mathrm{m}$.y. from $0.1 \mathrm{Ma}$ to the present.

Lithostratigraphic correlation between Sites 790 and 791 is based on the following characteristics: (1) lithology and sedimentary facies (Fig. 41 in "Sites 790/791" chapter, this volume); (2) identification of Key Bed \#7 (volcanic ash) at both sites (Fig. 13 in "Sites 790/791" chapter); (3) bulk magnetic susceptibility (Fig. 15 in "Sites 790/791" chapter); (4) carbonate contents (Fig. 42 in "Sites 790/791" chapter); and (5) seismic reflection records (see "Seismic Stratigraphy" section, "Sites $790 / 791$ " chapter). Correlation between the two sites is well constrained above Key Bed \#7, based mainly on the marked differences in magnetic susceptibility between thick units of felsic vitric silt (volume magnetic susceptibility $<125 \times 10^{-6}$ ), and thin- to thick-bedded intervals containing magnetic minerals and mafic grains of basaltic composition. These latter intervals include black vitric sand/silt beds and pumiceous gravels and pebbly sands (e.g., Site 791, 60-150 mbsf) that contain scattered scoria grains.
At Sites 790 and 791, there is a sharp lithologic contrast between Units I and II. Unit II, deposited between 1.1 and 0.2 $\mathrm{Ma}$, is burrowed nannofossil-rich clay, silty clay, and clayey silt, collectively $106 \mathrm{~m}$ thick at Site 790 (271-165 mbsf), and the lithified equivalents of these sediment types at Site 791, where the unit is $406 \mathrm{~m}$ thick (834-428 mbsf). The bedding in Unit II is subhorizontal in the sediments of Site 790 , but at Site 791 the dip gradually decreases upward from $45^{\circ}$ at 760 mbsf to only $15^{\circ}-20^{\circ}$ at about 600 mbsf. Unit I consists mainly of thick intervals of vitric silt. The contact between the two units is constrained to within $10 \mathrm{~m}$ at Site 790 (1.55-1.65 mbsf), although the contact itself was not recovered in cores. At Site 791, however, very poor recovery does not allow a confident assessment of the position of the contact based only on lithology. We therefore used four criteria to estimate the true depth of the contact between Units I and II at Site 791: (1) the lowest recovered bed of pumiceous sand, (2) a correlatable seismic horizon (see Fig. 6 in "Seismic Stratigraphy" section, "Sites 790/791" chapter, this volume), (3) the age correlation based on age-depth curves (Fig. 3 ), and (4) a comparison of downhole trends in carbonate content at the two sites.

At Site 790 , Unit II has carbonate contents of $20 \%-40 \%$, whereas Unit I has less than $20 \%$ carbonate (Fig. 42 in "Sites $790 / 791$ " chapter). The carbonate curve for Site 791 shows the same trend, with the upward transition from high to low carbonate values occurring at about $375-500$ mbsf. This depth is consistent with the independent estimate of the position of the contact between Units I and II at $\mathbf{4 2 8}$ mbsf, but it is not sufficiently defined in the carbonate curves to allow a more accurate definition of the contact.

\section{INTERPRETATION}

In brief, the results from the backarc sites document the following: rifting began no earlier than 3.56 (and probably 2.352.85) $\mathrm{Ma}$ and no later than $1.1 \mathrm{Ma}$. The region in pre-rift time underwent a period of relative volcanic quiescence that began prior to $4.77 \mathrm{Ma}$ and lasted to $4.2 \mathrm{Ma}$, terminated by a series of massive silicic eruptions that lasted until $4.1 \mathrm{Ma}$. The period from 4.1 to about 3.9 or $3.8 \mathrm{Ma}$ was characterized by another volcanic lull in the region, although distal volcanism provided thin ashfalls to Site 788. This lull was terminated by silicic eruptions that left at least three massive deposits of pumiceous gravels on what is now the rift flank uplift, and ended at a poorly constrained time that could have been as early as $2.85 \mathrm{Ma}$ or, more likely, as late or even later than $2.35 \mathrm{Ma}$.

Uplift of the rift flank sites, probably associated with the initiation of rifting, occurred some time after $\sim 2.8 \mathrm{Ma}$, causing erosional truncation of the sedimentary succession there. At the rift basin sites, rift initiation and emplacement of the igneous rocks occurred before $1.1 \mathrm{Ma}$; it was likely closer to this time than to $2.35 \mathrm{Ma}$. As rifting continued, there was first a period of relative volcanic quiescence, during which time the hemipelagic Unit II sediments of basin-floor Sites 790 and 791 accumulated. No contemporaneous sedimentary record is preserved on the rift flank. At about $0.2 \mathrm{Ma}$, renewed, episodic, explosive silicic volcanism resulted in the deposition of the Unit I pumiceous layers at the basin-floor sites and the uppermost $30 \mathrm{~m}$ of Site 788 on the rift flank uplift.

\section{REFERENCE}

Taylor, B., Brown, G., Hussong, D., and Fryer, P., 1988. SeaMARC II bathymetry, Sumisu and Torishima rifts, Izu-Ogasawara Arc, 1: 200,000. Mar. Geol. Map Ser., Tsukuba (Geol. Surv. Jpn.), No. 31.

\section{Ms 126A-112}

